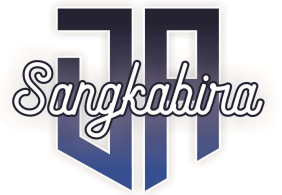

Vol. 1, No. 1, Desember 2020

\title{
PENINGKATAN KEMAMPUAN SUMBER DAYA MANUSIA (SDM) DALAM PENYUSUNAN RENCANA KERJA MELALUI KONSEP BALANCED SCORECARD (BSC) PADA KOPERASI
}

\author{
Isnawati, S.E,M.A \\ Dosen Fakultas Ekonomi Dan Bisnis Universitas Mataram \\ Isnawati.isna@unram.ac.id
}

Bq. Anggun HL, SE., M.Si., Ak

Dosen Fakultas Ekonomi Dan Bisnis Universitas Mataram

hilendria@unram.ac.id

\section{Lukman Effendy, SE., M.A}

Dosen Fakultas Ekonomi Dan Bisnis Universitas Mataram Lukman.effendy@unram.ac.id

\begin{tabular}{ll}
\hline Article History: & Abstrak: Konsep Balanced Scorecard(BSC) \\
Received: - & belakangan ini tampil sebagai alat ukur kinerja yang \\
Revised: - & diunggulkan melebihi alat ukur kinerja sebelumnya \\
Accepted: - & yang hanya mengandalkan satu aspek saja, yaitu \\
& aspek keuangan. Pada BSC ini melihat kinerja \\
& organisasi dari 4 aspek; yaitu aspek keuangan; \\
& aspek pelanggan; aspek bisnis Internal; dan aspek \\
pembelajaran dan pertumbuhan. Oleh karena itu tim \\
pengabdian menawarkan salah satu solusi yaitu \\
melakukan kegiatan pelatihan menghitung kinerja \\
koperasi dengan menggunakan alat ukur kinerja \\
Balanced Scorecard, serta membuat program kerja \\
berdasarkan konsep Balanced Scorecard tersebut. \\
Tujuan dilakukannya kegiatan pengabdian pada \\
masyarakat ini adalah untuk melatih pengurus \\
koperasi mengukur kinerja koperasinya dengan \\
menggunakan alat ukur Balanced Scorecard (BSC), \\
serta penyusunan rencana (program) kerjanya \\
dengan konsep Balanced Scorecard (BSC) tersebut. \\
Pendekatan/metode pelaksanaan kegiatan \\
pengabdian ini dilakukan dengan metode workshop \\
/ pelatihan, yaitu pelatihan pengukuran kinerja \\
koperasi dengan menggunakan alat ukur kinerja \\
Balaced Scorecard (BSC), serta menyusu program \\
kerja dengan pendekatan BSC tersebut. Target \\
luaran yang diharapkan dari kegiatan ini adalah \\
publikasi hasil kegiatan pengabdian berupa artikel \\
pada salah satu media masa di Nusa Tenggara Barat \\
(NTB). Kegiatan pengabdian dilaksanakan pada hari \\
senin tanggal 24 September 2018 berlokasi di kantor \\
a
\end{tabular}


pusat KSP Lombok Sejati yang berlamat di jalan Ahmad Yani No. 1 Gerimak Indah Kecamatan Narmada kabupaten Lombok Barat. Kegiatan berjalan lancar yang dilakukan menggunakan metode presentasi oleh tim pengabdian, baru kemudian dilakukan sesi diskusi antara tim pengabdian dengan pihak KSP Lombok Sejati. Pada dasarnya KSP Lombok Sejati sudah melakukan penilaian kinerja cukup meluas, tidak hanya berfokus pada aspek keuangannya saja, melainkan mencoba melakukan evaluasi pada aspek non keuangan seperti menggali sebab-sebab tidak tercapainya target yang sudah ditentukan sebelumnya oleh koperasi. Namun demikian, penilaian yang dilakukan di KSP tersebut belumlah tersistem dan belum lengkap sesuai dengan konsep Balanced Scorecard (BSC). Dengan demikian diharapkan setelah dilakukan kegiatan pengabdian ini, KSP Lombok Sejati bisa menjadikan konsep BSC sebagai alat ukur alternative selain penggunaan alat ukur yang biasa digunakan. Karena penilaian kinerja menggunakan konsep BSC bisa dijadikan dasar mendesign strategi bisnis di masa yang akan datang.

Kata Kunci: Kinerja; Balanced Scorecard ; Koperasi

\section{Latar Belakang}

Balanced scorecard diperkenalkan oleh Kaplan dan Norton (1990) melalui suatu riset tentang "pengukuran kinerja dalam organisasi". Dalam konsep Balanced Scorecard ini, sesungguhnya selain perspektif keuangan tetapi juga perspektif non keuangan yang wajib digunakan untuk mengukur kinerja perusahaan. Dengan kata lain, evaluasi terhadap kinerja perusahaan tidak lagi hanya mengandalkan pada persepktif keuangan, tetapi juga perspektif non keuangan. Idealnya, setiap manajemen perusahaan memerlukan alat ukur untuk mengetahui seberapa baik performa perusahaan. Objek yang selalu diukur adalah aspek keuangan.

Perkembangan ilmu pengetahuan dan teknologi, system pengukuran kinerja perusahaan yang semula hanya mengandalkan perspektif keuangan, dirasakan tidak cukup untuk menjamin kesinambungan perusahan. Kenyataan inilah yang menjadi awal terciptanya konsep balanced scorecard. 


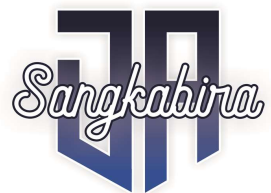

Vol. 1, No. 1, Desember 2020

Istilah balanced scorecard terdiri dari 2 kata yaitu balanced (berimbang) dan scorecard (kartu skor). Kata berimbang (balanced) dapat diartikan kinerja diukur secara berimbang dari sisi, yaitu sisi keuangan dan non keuangan, mencakup jangka pendek dan jangka panjang serta melibatkan bagian internal dan eksternal. Sedangkan pengertian kartu skor (scorecard) adalah suatu kartu yang digunakan untuk mencatat skor hasil kinerja, baik untuk kondisi sekarang ataupun untuk perencanaan di masa yang akan datang.

Hasil studinya menyimpulkan bahwa untuk mengukur kinerja masa depan, diperlukan pengukuran yang komprehensif yang mencakup 4 perspektif yaitu: keuangan, pelanggan (customer), proses bisnis intern, dan pembelajaranpertumbuhan. Bagaimana balanced scorecard ditinjau dari sistem manajemen strategic perusahaan ?.

Di dalam sistem manajemen strategik (Strategik management system)

ada 2 tahapan penting yaitu tahapan perencanaan dan implementasi. Posisi balanced scorecard awalnya berada pada tahap implementasi saja yaitu sebagai alat ukur kinerja secara komprehensif untuk memberikan feedback tentang kinerja manajemen. Dampak dari keberhasilan penerapan balanced scorecard memicu para eksekutif untuk menggunakan balanced scorecard pada tahapan yang lebih tinggi yaitu perencanaan strategik. Mulai saat itu, balanced scorecard tidak lagi digunakan sebagai alat pengukur kinerja namun berkembang menjadi strategik management sistem. Dalam kerangka dan perkembangan ini, menjadi wajar dikemudian hari balance srorecard menjadi instrumen (tool) untuk perencanaan sekaligus evaluasi.

Koperasi adalah salah satu badan usaha yang memiliki rencana (program) kerja. Menurut Permen Koperasi dan Usaha Kecil dan Menengah RI Nomor 21/Per/M.KUKM/IX/2015 tentang Pemeringkatan Koperasi pasal 1 menyatakan bahwa Koperasi adalah badan usaha yang beranggotakan orang seorang atau badan hukum koperasi dengan melandaskan kegiatannya berdasarkan prinsip koperasi sekaligus sebagai gerakan ekonomi rakyat yang berdasar atas asas kekeluargaan. Selanjutnya permen tersebut juga menyatakan bahwa koperasi berkualitas adalah koperasi yang memiliki kinerja baik dalam bidang kelembagaan, usaha, keuangan serta bermanfaat bagi anggota sebagai badan hukum aktif dan badan usaha yang dicirikan oleh prinsip-prinsip kohesivitas dan partisipasi 
anggota yang kuat dengan kinerja usaha yang semakin sehat dan berorientasi kepada usaha anggota serta memiliki kepedulian social.

Sejauh ini koperasi yang berkualitas dilihat dari peringkat yang dimiliki oleh koperasi tersebut berdasarkan Peraturan Menteri. Peringkat tersebut menunjukkan keberhasilan dan eksistensi koperasi kepada pihak-pihak yang berkepentingan. Berdasarkan Permen Koperasi dan Usaha Kecil dan Menengah RI Nomor 21/Per/M.KUKM/IX/2015 tentang Pemeringkatan Koperasi pasal 4 menyatakan bahwa ruang lingkup pemeringkatan koperasi meliputi 5 (lima) aspek koperasi yang meliputi; a) aspek kelembagaan koperasi; b) aspek usaha koperasi; c) aspek keuangan koperasi; d) aspek manfaat koperasi terhadap anggota; e) aspek manfaat koperasi terhadap masyarakat.

Permen Koperasi pasal 6 menyatakan bahwa Pemeringkatan koperasi dilakukan oleh Lembaga Independen yang memiliki kompetensi dibidangnya serta telah diakreditasi sesuai Peraturan yang berlaku sebagai Lembaga Independen Pemeringkat Koperasi (LIPK). Melihat kenyataan seperti itu, jelaslah bahwa koperasi tidak bias melakukan pemeringkatan untuk dirinya sendiri. Sehingga yang biasa dilakukan oleh koperasi selama ini untuk mengetahui kinerjanya adalah sebatas menghitung kinerja keuangannya saja dengan melihat struktur permodalan, kondisi kemampuan penyediaan dana, serta ukuran-ukuran kuantitatif lainnya seperti prosentase pelunasan simpanan wajib, dan prosentase besaran simpanan sukarela.

Perhitungan kinerja dengan hanya melihat aspek keuangan saja, tentu belum mampu memberikan gambaran kinerja koperasi secara menyeluruh, terlebih lagi jika dipakai sebagai alat perencanaan koperasi.

\section{A. Permasalahan dan Solusi yang ditawarkan}

Beradasarkan latar belakang di atas yang menunjukkan kelemahan alat ukur kinerja koperasi yang belum mampu memperlihatkan kinerja (prestasi) secara menyeluruh, mengingat penilaian kinerja umumnya berorientasi pada aspek keuangan saja. Selain itu alat pengukuran kinerja yang umumnya digunakan pada koperasi tersebut juga belum mampu dijadikan sebagai dasar melakukan perencaan program kerja koperasi di masa yang akan datang.

Konsep Balanced Scorecard(BSC) belakangan ini tampil sebagai alat ukur kinerja yang diunggulkan melebihi alat ukur kinerja sebelumnya yang hanya mengandalkan satu aspek saja, yaitu aspek keuangan. Pada BSC ini melihat kinerja organisasi dari 4 aspek; yaitu aspek keuangan; aspek 
Vol. 1, No. 1, Desember 2020

pelanggan; aspek bisnis Internal; dan aspek pembelajaran dan pertumbuhan. Oleh karena itu tim pengabdian menawarkan salah satu solusi yaitu melakukan kegiatan pelatihan menghitung kinerja koperasi dengan menggunakan alat ukur kinerja Balanced Scorecard, serta membuat program kerja berdasarkan konsep Balanced Scorecard tersebut.

\section{B. Tujuan Dan Manfaat}

\section{Tujuan}

Tujuan dilakukannya kegiatan pengabdian pada masyarakat ini adalah untuk melatih pengurus koperasi mengukur kinerja koperasinya dengan menggunakan alat ukur Balanced Scorecard (BSC), serta penyusunan rencana (program) kerjanya dengan konsep Balanced Scorecard (BSC) tersebut.

\section{Manfaat}

Kegiatan pengabdian pada Masyarakat ini diharapkan dapat meningkatkan kemampuan Sumber Daya Manusia (SDM) koperasi dalam pengukuran kinerja serta penyusunan rencana (program) kerjanya dengan konsep Balanced Scorecard (BSC).

\section{Target Luaran}

Target luaran yang diharapkan dari kegiatan ini adalah publikasi hasil kegiatan pengabdian berupa artikel pada salah satu media masa di Nusa Tenggara Barat (NTB) atau publikasi pada salah satu Jurnal Pengabdian skala Nasional tidak terkareditasi .

\section{Pendekatan/ Metode Pelaksanaan kegiatan}

Pendekatan/metode pelaksanaan kegiatan pengabdian ini dilakukan dengan metode workshop / pelatihan, yaitu pelatihan pengukuran kinerja koperasi dengan menggunakan alat ukur kinerja Balaced Scorecard (BSC), serta menyusu program kerja dengan pendekatan BSC tersebut.

\section{E. Personalia}

Kegiatan pengabdian pada masyarakat ini dilaksanakan oleh tim dari dosen Fakultas Ekonomi dan Bisnis Universitas Mataram yang memiliki kualifikasi Pendidikan dan pengalaman yang memadai di bidangnya. Tim pengabdian memiliki tingkat Pendidikan rata-rata Strata 2(S2) dan memiliki bidang akuntansi keuangan dan Akuntansi Sektor Publik, sehingga dirasakan sangat layak dalam memberikan pelatihan 
mengenai pengukuran kinerja koperasi menggunakan alat ukur kinerja Balanced Scorecard.

\section{F. Lokasi Kegiatan}

Kegiatan Pengabdian pada Masyarakat ini dilaksanakan pada Koperasi Simpan Pinjam (KSP) Lombok Sejati yang beralamat di Jalan Ahmad Yani no.1 Gerimak Indah. Adapun pemilihan lokasi ini dikarenakan KSP Lombok Sejati merupakan salah satu KSP yang cukup besar di provinsi Nusa Tenggara Barat dengan tata kelola yang juga sangat baik. Hal ini dibuktikan dengan masih aktifnya koperasi tersebut, bahkan sudah berhasil membuka cabang di kapubaten Lombok Timur, Lombok Tengah maupun yang lainnya.

\section{G. Jadwal Kegiatan}

Kegiatan pengabdian ini akan dilaksanakan selama 3 bulan, dengan rincian sebagai berikut:

\begin{tabular}{|l|l|l|l|l|l|l|l|l|}
\hline \multirow{2}{*}{ No } & \multicolumn{1}{|c|}{ Kegiatan } & \multicolumn{7}{c|}{ Bulan } \\
\cline { 3 - 9 } & & $\mathbf{5}$ & $\mathbf{6}$ & $\mathbf{7}$ & $\mathbf{8}$ & $\mathbf{9}$ & $\mathbf{1 0}$ & $\mathbf{1 1}$ \\
\hline 1 & $\begin{array}{l}\text { Pendahuluan: } \\
\text { Suvey Pendahuluan }\end{array}$ & & & & & & & \\
\hline 2 & $\begin{array}{l}\text { Pelaksanaan: } \\
\text { Pelatihan danDiskusi }\end{array}$ & & & & & & & \\
\hline 3 & Evaluasi & & & & & & & \\
\hline 4 & Penyusunan Laporan & & & & & & & \\
\hline
\end{tabular}

\section{H. Hasil Kegiatan}

\section{Gambaran Umum Lokasi Kegiatan}

Kegitan pengabdian ini dilakukan pada Koperasi Simpan Pinjam Lombok Sejati. Pemilihan KSP Lombok Sejati sebagai lokasi kegiatan, salah satu alasannya dikarenakan KSP ini merupakan salah salah satu Koperasi yang tergolong besar di Nusa Tenggara Barat, sehingga memungkinkan untuk diterapkan Balanced Scorecard sebagai alat ukur alternative dalam menilai kinerja koperasi.Koperasi Simpan Pinjam Lombok Sejati, pada awal berdirinya merupakan binaan Dinas Koperasi Kota Mataram, Terdaftar sesuai badan hukum nomor : 518/058/BH/DISKOP\&PKM/2004, pada tanggal 13 Maret 2004,Koperasi Lombok Sejati memulai usahanya berkantor di Jalan Jendral Sudirman No. 1 Rembiga Mataram dan membuka cabang cabang di berbagai tempat di pulau Lombok dan memberikan pelayanan berupa pinjaman dan simpanan. Saat ini produk simpanan yang ada di Koperasi Lombok Sejati antara lain Simpanan 


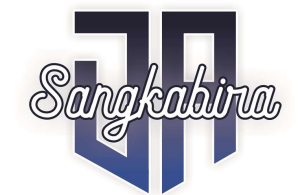

Vol. 1, No. 1, Desember 2020

masa depan, Simpanan masa depan multi guna, simpanan Haji Labbaikka,Talangan Haji dan simpanan berjangka . Setelah membuka beberapa kantor cabang yang tersebar di Pulau Lombok, pengurus dan anggota sepakat melakukan perubahan anggaran dasar yang telah mendapat persetujuan dari Kementerian Koperasi Usaha Kecil dan Menengah Republik Indonesia dengan nomor : 518/040/BH/PAD/DISKOP \& UKM/V/2006, pada tanggal 26 bulan mei tahun 2006. Koperasi Simpan Pinjam Lombok Sejati merupakan koperasi dengan status primer propinsi yang khusus bergerak di bidang simpan pinjam seiring perkembangan bekerjasama dengan lembaga perbankan (melalui Linkage program baik channelling maupun executing) dan lembaga non perbankan dapat memberikan pelayanan seperti dana talangan Haji, tempat pembayaran Rekening Listrik, Telpon, kiriman uang dari luar negeri (Cash Out Chanel tRemitt...) dan terus akan di kembangkan pelayanan dibidang lain yang bermanfaat bagi anggota dan masyarakat. Untuk mendukung pelayanan dan meningkatnya akan produk-produk yang diminati maka Koperasi Lombok Sejati terus akan bermitra dengan lembaga lain baik secara vertikal maupun horizontal seperti Lembaga Pengelola Dana Bergulir (LPDB), PT. Bank Syariah Mandiri, PT. Permodalan Nasional Madani, PT. Telkomsel, Induk Koperasi Simpan Pinjam (IKSP), PT. Bank Muamalat Indonesia, PT. Bank Tabungan Negara, PT. Bank Bukopin dan instansi-instansi lainnya baik pemerintah maupun swasta, dengan didukung oleh berbagai pihak, Mitra usaha dan bimbingan dari Kementerian Negara Koperasi dan Usaha Kecil, Menengah Republik Indonesia melalui Dinas Koperasi Propinsi Nusa Tenggara Barat serta Dewan Koperasi Indonesia (Dekopin) Koperasi Simpan Pinjam Lombok Sejati terus berkembang bersama mitra kerjanya untuk melaksanakan Misi dan mewujudkan Visinya menjadi Koperasi yang Sehat, Mandiri serta Unggul dibidangnya (ksplomboksejatintb.wordpress.com).

\section{Hasil Kegiatan}

Kegiatan pengabdian dilaksanakan pada kantor pusat KSP Lombok Sejati yang berlokasi di Jalan Ahmad Yani No. 1 Gerisak Indah, Kec. Narmada, Kabupaten Lombok Barat. Berlangsung pada hari senin tanggal 24 September 2018 pukul 09.00 WITA sampai dengan selesai.

Kegiatan berlangsung lancar yang dihadiri langsung oleh pimpinan dan wakil pimpinan serta beberapa karyawan KSP Lombok Sejati untuk mengikuti acara sosialisasi tentang pengukuran kinerja pada koperasi dengan menggunakan alat ukur Balanced Scorecard. Metode penyampaian sosialisasi diawali dengan presentasi oleh tim pengabdian menggunakan media LCD projector yang disediakan 
langsung oleh pihak KSP sendiri, setelah itu baru kemudian dilakukan sesi tanya jawab tentang materi yang disampaikan serta melihat kemungkinan bisa tidaknya alat ukur ini diterapkan pada koperasi tersebut untuk dijadikan sebagai alat ukur alternative selain alat ukur yang digunakan selama ini. Mengingat alat ukur Balanced Scorecard ini memiliki banyak keunggulan, salah satunya sebagai alat perencanaan strategi bisnis.

Kegiatan mendapatkan dukungan penuh dari koperasi, terlihat dari sambutan baik pimpinan maupun pihak lainnya yang ada di koperasi, serta penyediaan lokasi dengan berbagai sarana yang diperlukan seperti LCD projector untuk presentasi tim pengabdian.

Berdasarkan hasil diskusi yang berlangsung pada saat kegiatan berlangsung, terlihat adanya ketertarikan dari pihak koperasi untuk mencoba melakukan pengukuran kinerja dengan menggunakan BSC tersebut, terlebih lagi setelah ditelusuri bahwa pada dasarnya Koperasi ini sebagian dari penilaian kinerja sudah menerapkan konsep Balanced Scorecard. Karena penilaian kinerja yang dilakukan tidak hanya berfokus pada aspek kinerja/prestasi dibidang keuangan KSP saja, melainkan di aspek non keuanganpun dilakukan seperti kompetensi karyawan. Melakukan evaluasi terhadap sebab-sebab Koperasi belum mencapai target yang ditentukan. Namun demikian, penilaian tersebut belum tersistem seperti konsep Balanced Scorecard yang mengusung penilaian kinerja dari 4 (empat) perspektif (aspek) yaitu perspektif keuangan; pelanggan, Proses Bisnis Internal; dan perspektif Pertumbuhan dan pembelajaran. Adapaun materi presentasi kegiatan pengabdian lebih lengkapnya dapat dilihat pada lampiran 1.

Dengan demikian dapat dikatakan bahwa kegiatan ini sangat bermanfaat bagi koperasi, karena melalui kegiatan ini koperasi bisa mengenal alat ukur kinerja BSC dengan detail. Diharapkan ke depannya koperasi mampu menjadikan konsep BSC ini dalam menilai kinerja koperasi sehingga bisa dilakukan perencanaan bisnis yang lebih tersistem sesuai dengan visi dan misi yang dibangun oleh koperasi.

\section{Kesimpulan dan Rekomendasi}

\section{Kesimpulan}

Kegiatan pengabdian dilaksanakan pada hari senin tanggal 24 September 2018 berlokasi di kantor pusat KSP Lombok Sejati yang berlamat di jalan Ahmad Yani No. 1 Gerimak Indah Kecamatan Narmada kabupaten Lombok Barat. Kegiatan berjalan lancar yang dilakukan menggunakan metode presentasi oleh tim pengabdian, baru kemudian dilakukan sesi diskusi antara tim pengabdian dengan pihak KSP Lombok Sejati. 


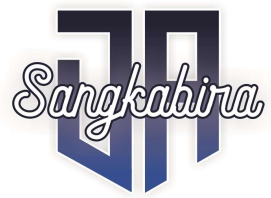

Vol. 1, No. 1, Desember 2020

Pada dasarnya KSP Lombok Sejati sudah melakukan penilaian kinerja cukup meluas, tidak hanya berfokus pada aspek keuangannya saja, melainkan mencoba melakukan evaluasi pada aspek non keuangan seperti menggali sebab-sebab tidak tercapainya target yang sudah ditentukan sebelumnya oleh koperasi. Namun demikian, penilaian yang dilakukan di KSP tersebut belumlah tersistem dan belum lengkap sesuai dengan konsep Balanced Scorecard (BSC). Dengan demikian diharapkan setelah dilakukan kegiatan pengabdian ini, KSP Lombok Sejati bisa menjadikan konsep BSC sebagai alat ukur alternative selain penggunaan alat ukur yang biasa digunakan. Karena penilaian kinerja menggunakan konsep BSC bisa dijadikan dasar mendesign strategi bisnis di masa yang akan datang.

\section{Rekomendasi}

Mengingat konsep BSC menawarkan berbagai keunggulan dalam pengukuran kinerja perusahaan, tidak terkecuali bagi koperasi untuk mengantisipasi banyaknya koperasi yang mulai tidak aktif beroperasi di Nusa Tenggara Barat. Hanya beberapa koperasi yang mampu bertahan. Maka perlu dilakukan kegiatan yang sama di koperasi-koperasi lainnya dalam rangka memperkenalkan konsep BSC dalam penilaian kinerja perusahaan maupun dalam mendisain strategi bisnisnnya. Sehingga ke depan koperasi mampu memenangkan persaingan bisnis. Selain itu, bagi regulator dalam hal ini Dinas Koperasi Propinsi Nusa Tengga Barat bisa menjadikan konsep BSC ini sebagai rekomendasi regulasi di masa yang akan datang terkait dengan alat ukur kinerja koperasi. Karena konsep BSC ini setidaknya lebih mampu memperlihatkan kondisi perusahaan dari berbagai sisi, lebih tepatnya dari 4 sisi yang dituangkan oleh Kaplan dan Norton yaitu sisi keuangan; pelanggan, Proses Bisnis Internal dan dari sisi Pembelajaran dan Pertumbuhan.

\section{J. Daftar Pustaka}

Iskandar, M Soesilo (2008) Dinamika Gerakan Koperasi Indonesia. PT Wahana Semesta Indonesia. Jakarta.

Kaplan. RS and Norton. DP (1996) Balanced Scorecard. Harvard Bisiness Schoo Press. Boston Massachuted.

Kirkpatrick. D. (1998). Evaluating Training Programe. Berrett Koehler Publisher. Inc. San Fransisco.

Luis. S (2007) Balanced Scorecard. PT Gramedia Pustaka Utama. Jakarta. 
Niven. PR (2003) Balanced Scorecard Step by Step for Government and Nonprofit Agencies. John Wiley and Sons. New Jersey.

Peraturan Menteri Koperasi Dan Usaha Kecil Dan Menengah Republik Indonesia Nomor 21/Per/M.Kukm/Ix/2015 Tentang Pemeringkatan Koperasi.

Wheelen TL and Hunger JD (1991) Strategic Management and Business Policy. Addison Wesley Publisher Company. Massachusetts.

\section{Lampiran 2: Dokumentasi Kegiatan}

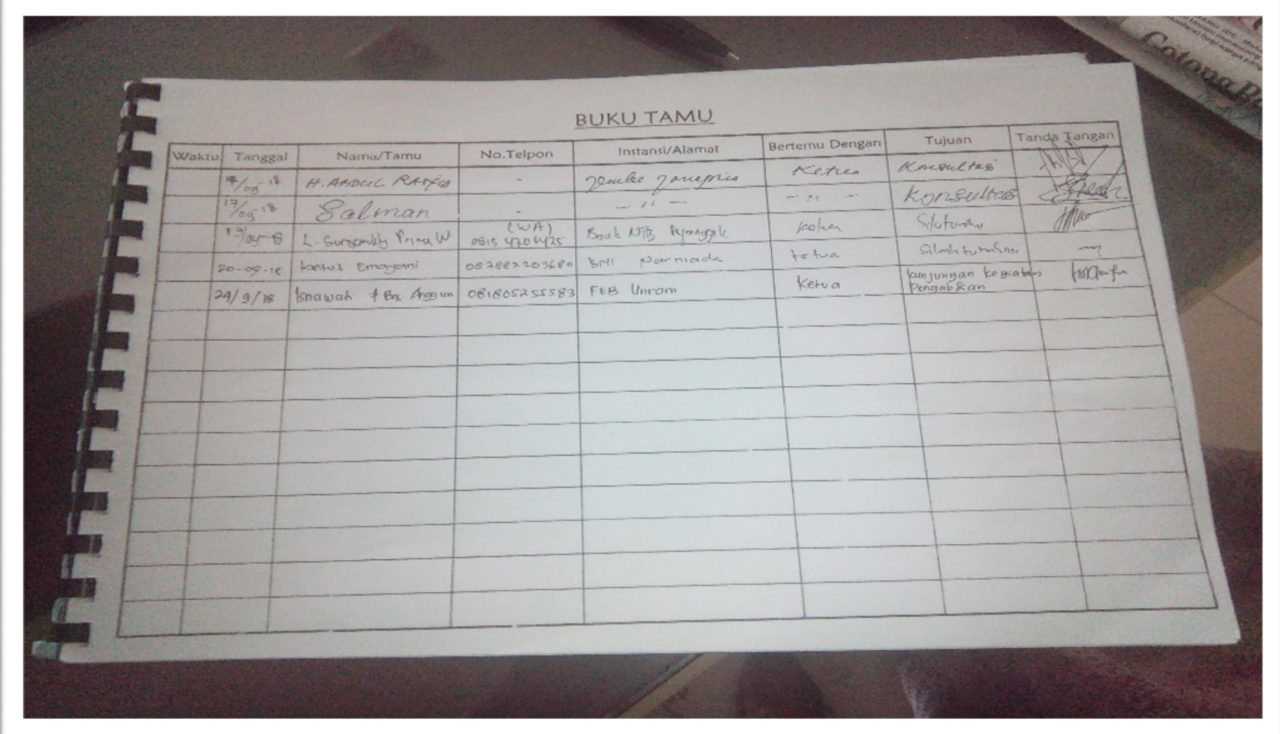

Gambar 1 : Bukti Hadir tim Pengabdian pada KSP Lombok Sejati 


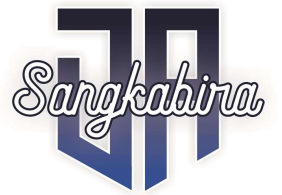

Vol. 1, No. 1, Desember 2020

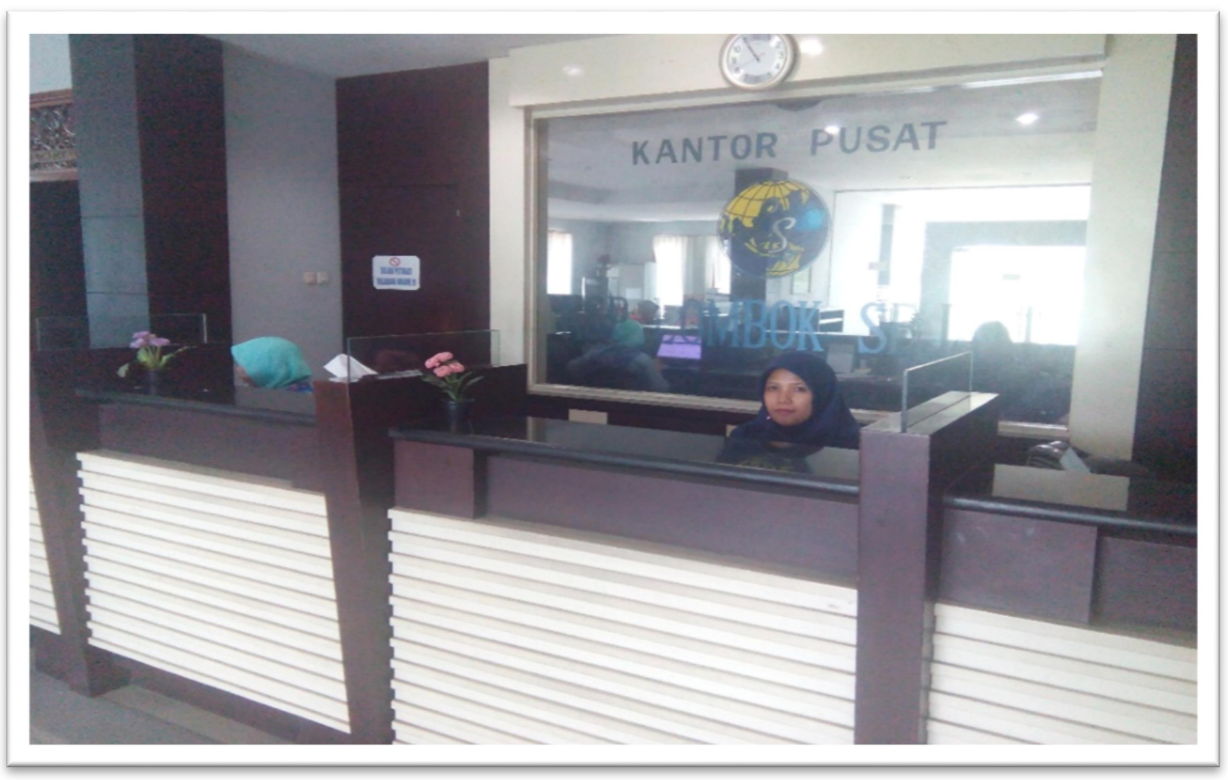

Gambar 2 : tim pengabdian Bertemu bagian Resepsionis untuk membuat janji dengan pihak KSP dalam rangka Kegiatan Pengabdian Kepada Masyarakat

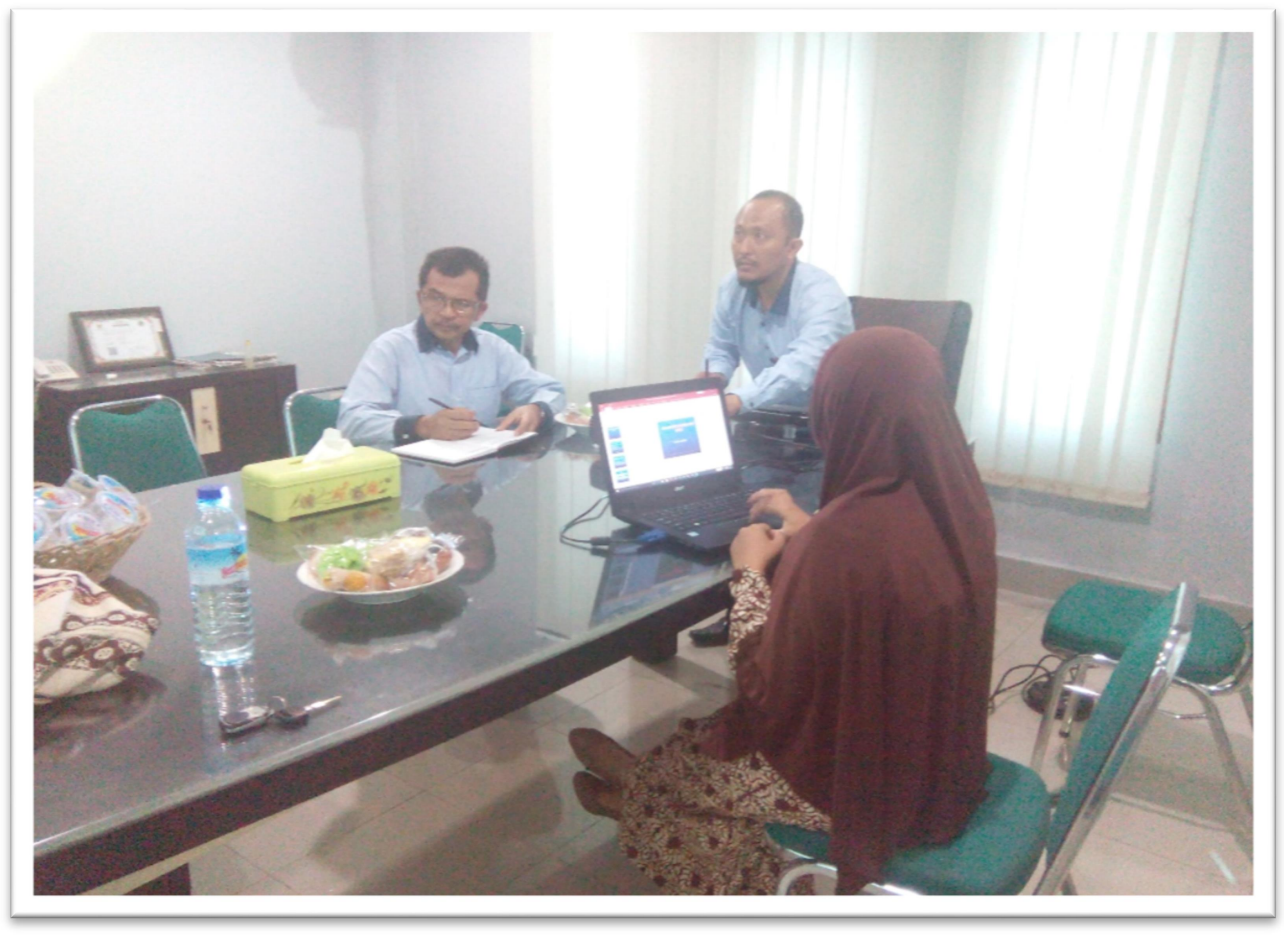

Gambar 3 : Tim Pengabdian mempresentasikan materi pengabdian mengenai Konsep Balanced Scorecard (BSC) 


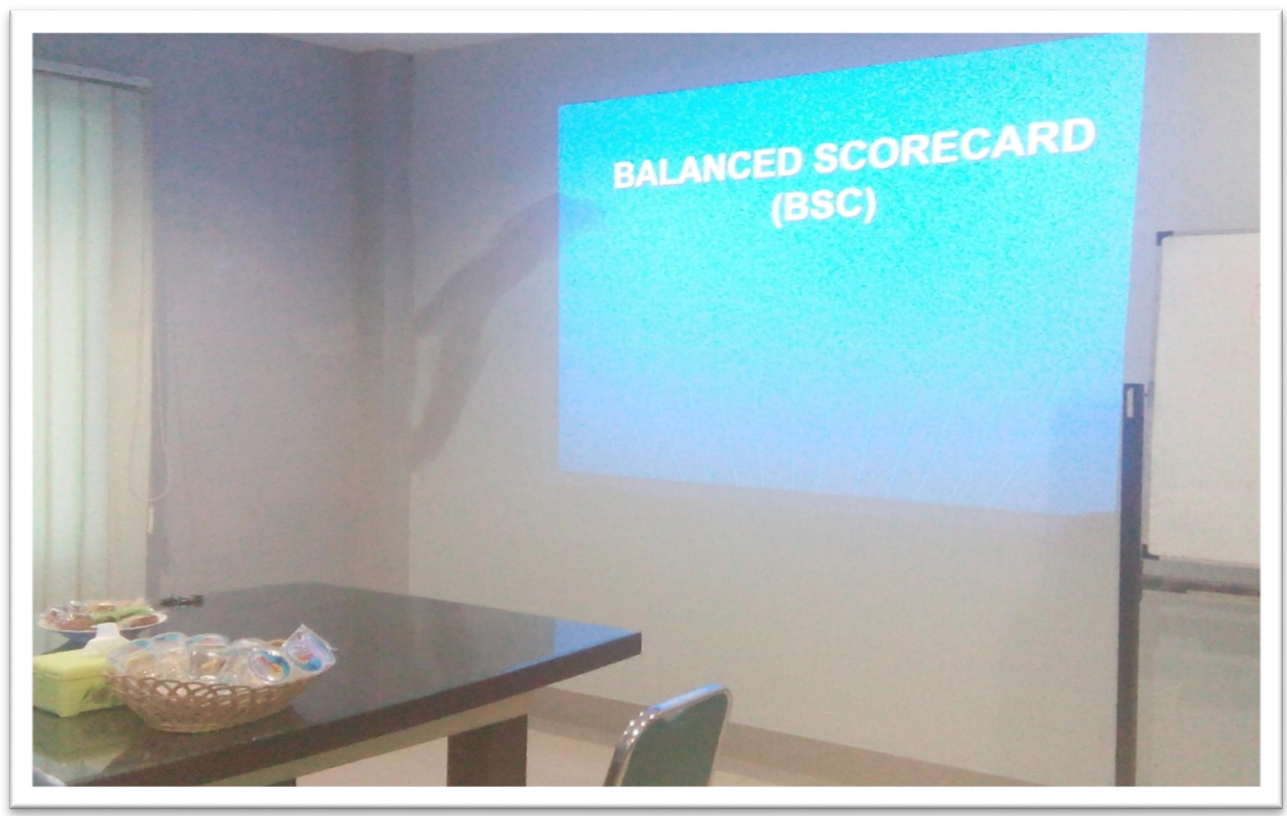

Gambar 4 : Materi Presentasi kegiatan Pengabdian

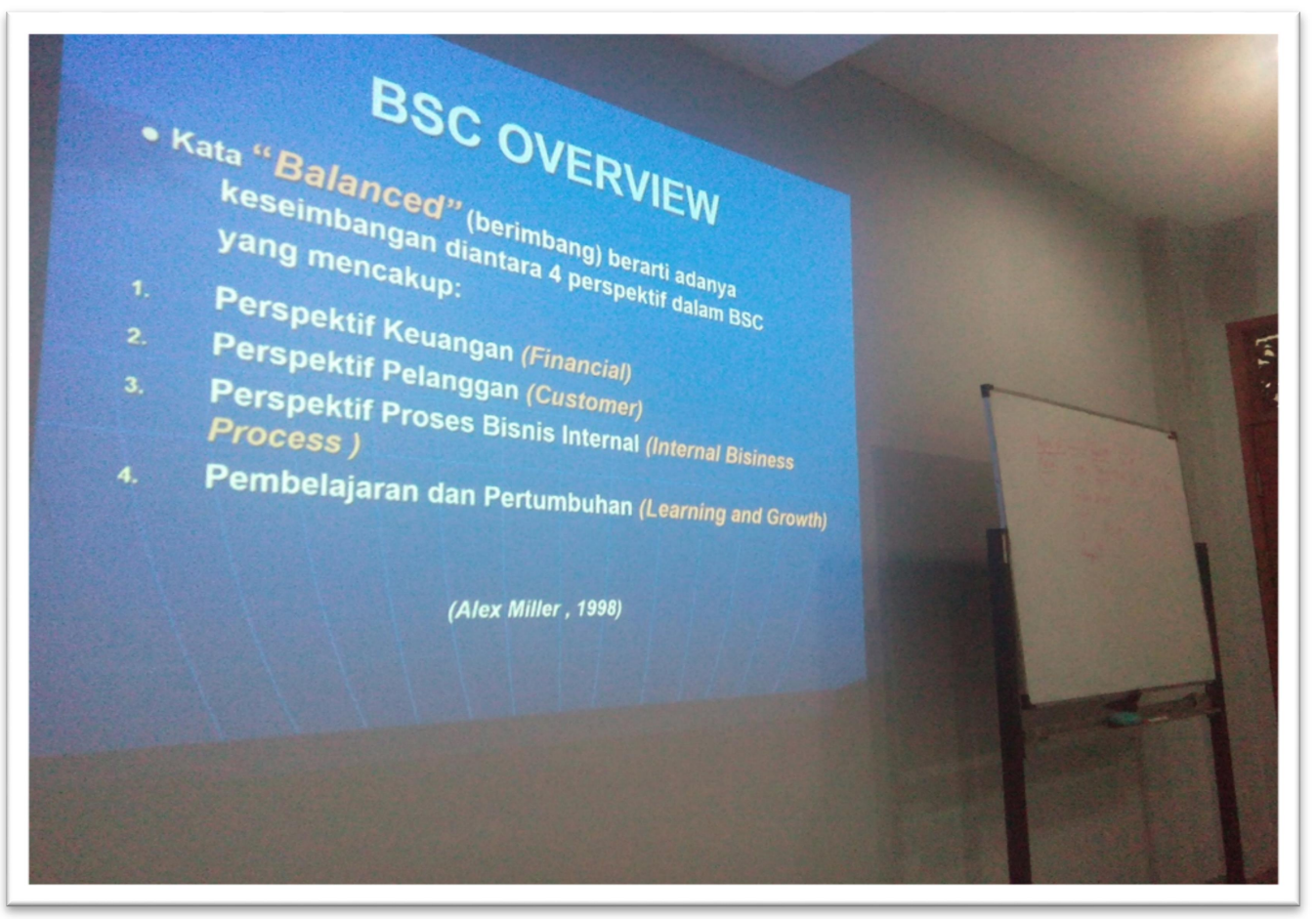

Gambar 5 : Materi Presentasi kegiatan Pengabdian tentang BSC 


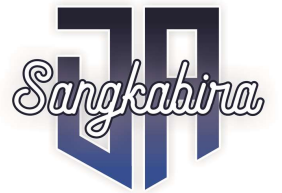

Vol. 1, No. 1, Desember 2020

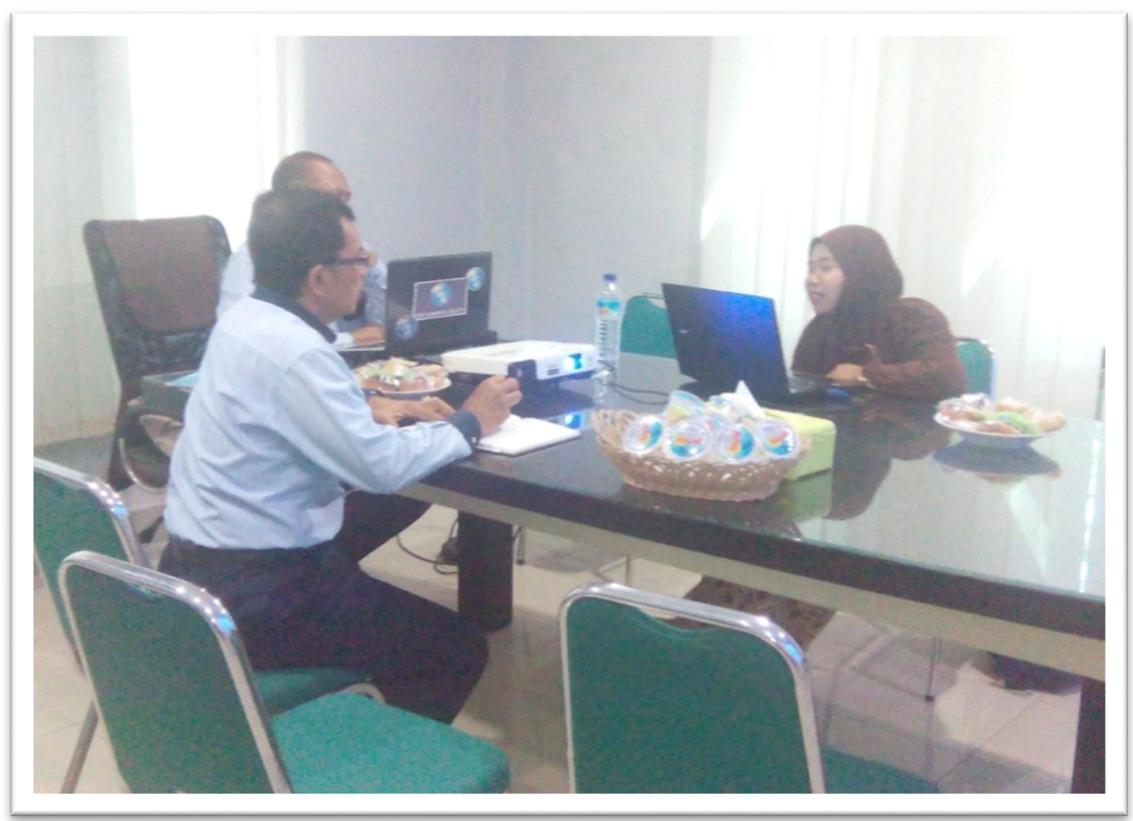

Gambar 6 :Sesi diskusi tim pengabdian dengan pengurus Lombok Sejati terkait materi BSC 